\title{
Клінічний випадок трансформації дерматофіброми у фібросаркому
}

\author{
Національний інститут раку, Київ \\ Одержано 26.05.2019 \\ Прийнято до друку 22.07.2019 \\ DOI: $10.32471 /$ clinicaloncology.2663-466X.39.22612
}

\begin{abstract}
Шлях трансформації доброякісного новоутворення в злоякісну пухлину досить складний та до теперішнього часу мало досліджений. Описано клінічний випадок тривалої трансформації (23 роки) доброякісної фіброзної гістіоцитоми (дерматофіброми) у дерматофібросаркому вибухаючу, яка в подальшому трансформувалася у фібросаркому.
\end{abstract}

Ключові слова: доброякісна фіброзна гістіоцитома (дерматофіброма); дерматофібросаркома вибухаюча; фібросаркома; клінічний випадок.

\section{ВСТУП}

Доброякісну фіброзну гістіоцитому (ДФГ; дерматофіброма) іноді трактують як проміжну пухлину між доброякісною та злоякісною формами. Спостерігається значне гістологічне та імунофенотипове перекриття при дослідженні даних пухлин, і зважаючи на малу кількість випадків, дерматопатологи і патологи часто не знають основних діагностичних критеріїв.

Дерматофіброма становить 3\% від загальної кількості всіх новоутворень шкіри, що фіксуються патологоанатомічними лабораторіями [4]. Загальний рівень захворюваності в усьому світі важко визначити, оскільки переважна більшість пацієнтів ніколи не звертаються із цими ураженнями. Їх найчастіше виявляють у пацієнтів віком від 20 до 40 років. Більшість досліджень свідчать, що цю патологію удвічі частіше виявляють у жінок порівняно з чоловіками [10].

ДФГ (дерматофіброма) відносять до доброякісних пухлин [1] на основі подібних клінічних і гістологічних особливостей. Дані новоутворення, як правило, мають розмір до 1 см у діаметрі, але можуть досягати 10 см. Найчастіше відмічається враження кінцівок, ураження голови, шиї й обличчя є нетиповим для даного типу пухлини, за винятком клітинного варіанту дерматофіброми [7]. ДФГ часто представлена як поверхневе, папулонодулярне новоутворення із мінливою пігментацією, що повільно росте. У цілому даний тип пухлини має сприятливий прогноз, проте останнім часом з'являються повідомлення про переродження пухлин даного типу в більш агресивні форми новоутворень, що найчастіше пов'язано з некоректно проведеним хірургічним або іншими видами лікування [11]. Зокрема, такі гістологічн підтипи дерматофіброми, як глибокий та атиповий гістотип, а також дерматофіброми, які розташовані на обличчі, пов’язані з підвищеним ризиком місцевого рецидиву, який, за даними деяких досліджень, може досягати 20\% [3].

Для більш правильного розуміння можливості злоякісного переродження, яке розвинулося на фоні рецидиву після проведеного лікування ДФГ, необхідно проводити як гістологічне, так й імуногістохімічне дослідження первинної пухлини й рецидиву.

Диференційну діагностику ДФГ слід проводити насамперед із дерматофібросаркомою вибухаючою (ДФСВ).

ДФСВ - це рідкісна пухлина, яка характеризується локально-агресивним ростом, високою частотою рецидивування і водночас низьким ризиком метастазування. Основною ознакою ДФСВ є місцево-деструктивний ріст і висока частота рецидивування після хірургічного лікування - до 60\% [5]. Так, за даними літератури, частота рецидивування ДФСВ при економному висіченні (відступ від краю пухлини $<1$ см) становить від 20 до 60\% [6]. Після широкого висічення (2-3 см) локальні рецидиви виникають значно рідше - від 0 до $30 \%$ [6], а при від- ступі 5 см частота виникнення рецидивів становить менше $5 \%$ [2]. Таким чином, збільшення відступу від краю пухлини достовірно знижує частоту місцевих рецидивів.

Щодо гістологічних ознак, то ДФСВ складається з досить мономорфної проліферації тонких, еозинофільних шпиндельних клітин з яскраво забарвленими ядрами, які ростуть дифузно-інфільтративно в підшкірній клітковині й майже у всіх випадках проявляють інтенсивну дифузну експресію CD34. Пігментовані форми ДФСВ (пухлини Беднара) можуть містити змішаний білок S100 і мелано-позитивні меланоцити. Більшість ДФСВ не має інших змішаних типів клітин, що демонструють експресію маркерів, таких як актини, CD163. Хоча багато патологів вважають, що ДФГ має мати позитивний фактор ХІІІа, це насправді не так. Найбільш характерною особливістю ДФГ, яку виявляють імуногістохімічно, $є$ наявність численних клітинних популяцій, включаючи білок фактора XIIIa, CD34, S100 і CD68-позитивні клітини. Багато ДФГ демонструють обмежену міофібробластичну диференціацію у вигляді експресії актину гладких м'язів, що не слід інтерпретувати як прояв лейоміосаркоми, оскільки ДФГ може проявляти мітотичні фігури та вогнища некрозу. У виняткових випадках для проведення диференційної діагностики слід пам'ятати про ДФСВ-пов'язаний тромбоцитарний фактор росту, що є остаточним аргументом на користь встановлення діагнозу ДФСВ (таблиця).

Таблиця. Диференційна діагностика ДФГ, імуногістохімічні ознаки

\begin{tabular}{lllll}
\hline \multicolumn{1}{c}{ Антиген } & \multicolumn{1}{c}{ ДФГ } & \multicolumn{1}{c}{ ДФСВ } & \multicolumn{1}{c}{ ВДФМС } & \multicolumn{1}{c}{ ПН } \\
\hline CD34 & Варіабельно $^{1}$ & Позитивний & Рідко & Варіабельно \\
Фактор XIIIaа & Варіабельно $^{1}$ & Негативний & Негативний & Негативний \\
CD 163 & Варіабельно $^{1}$ & Негативний & Негативний & Негативний \\
EMA & Нггативний & Негативний & Варіабельно & Позитивний \\
MUC4 & Негативний & Негативний & Позитивний & Негативний \\
\hline
\end{tabular}

ВДФМС - високо диференційована фіброміксоїдна саркома; ПН - периневринома; 'ДФГ найчастіше проявляє позитивні домішки маркерів CD34, фактора XIIla i CD163, але ретельне обстеження часто показує, що ураження клітини є негативним для всіх тестованих маркерів.

Віддалені метастази при ДФСВ виявляють у $1-4 \%$ випадків [5], і смерть, пов'язана з прогресуванням пухлини, $\epsilon$ досить рідкісним явищем, проте спостерігаються випадки трансформації ДФСВ у фібросаркому [8], яка, у свою чергу, $€$ злоякісною пухлиною з високим рівнем агресивності.

Згідно з поточною статистикою Національного інституту раку (National Cancer Institute - NCI) Сполучених Штатів Америки, фібросаркоми, що виявлені у дорослих, становлять $3,6 \%$ від загальної частки всіх сарком м'яких тканин у дорослих [9]. Патогістологічно фібросаркома складається з відносно рівномірних шпиндельних клітин 3 надмірно високою швидкістю поділу. Характерно, що злоякісні клітини розта- 
шовуються у формі «ялинки». Імуногістохімічне дослідження при фібросаркомі є необхідним для диференційної діагностики із ДФСВ. Так, зокрема, при трансформації дерматофібросаркоми у фібросаркому у дорослих відбувається втрата рецепторного статусу CD34, який у ДФСВ є позитивним у $90 \%$ випадків.

\section{Клінічний випадок}

Даний клінічний випадок - це 23-річне спостереження історії трансформації проліферуючої дерматофіброми в низькодиференційовану фібросаркому.

50-річна жінка Н. уперше звернулася до центральної районної лікарні за місцем проживання, де 11.03 .1996 р. було проведено хірургічне лікування в обсязі висічення пухлини шкіри правого передпліччя. При патогістологічному дослідженні, яке в подальшому проводилося в Національному інституті раку (НІР), було верифіковано проліферуючу дерматофіброму (рис. 1).

Через 2 роки після проведення вищевказаного лікування у хворої було відмічено рецидив захворювання у вигляді пухлинного вузла діаметром до $3 \mathrm{~cm}$, із блискучою поверхнею. Хвора звернулася в НІР, де 28.01.1998 р. було проведено інцизійну біопсію новоутворення, у ході якої було патогістологічно верифіковано ДФСВ G1 (рис. 2).

У передопераційний період хворій з 05.02.1998 p. до 15.02 .1998 р. проведено курс променевої терапії сумарною осередковою дозою (СОД) 20 Грей із наступним етапом 28.02.1998 р. хірургічного лікування в обсязі широкого висічення пухлини м'яких тканин правого передпліччя. У піс-

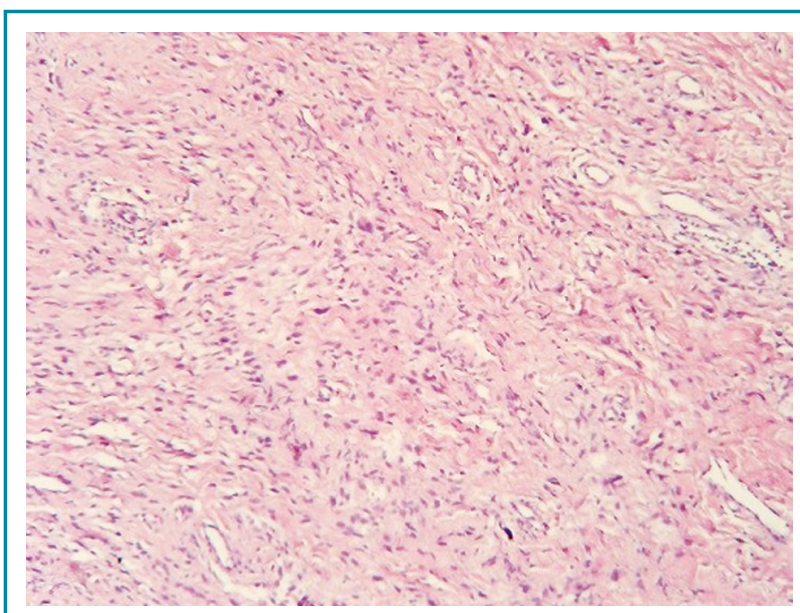

Рис. 1. Проліферуюча дерматофіброма; забарвлення гематоксиліном та еозином, $\times 40$ ляопераційний період з 10.03.1998 р. до 17.03 .1998 р. хворій проведено курс променевої терапії СОД 15 Грей.

16.01.2002 р. хвора повторно звернулася в НІР зі скаргами на рецидив захворювання, який проявлявся наявністю пухлинного вузла в післяопераційному рубці шкіри правого передпліччя розмірами $2 \times 1,5 \times 1,0 \mathrm{~cm}$, після чого пацієнтці 22.01 .2002 р. було проведено хірургічне лікування в обсязі широкого висічення післяопераційного рубця із наявною в останньому пухлиною. Згідно із патогістологічною верифікацією спостерігався рецидив ДФСВ (рис. 3).

У 2011 р. пацієнтка знову звернулася в НІР зі скаргами на наявність рецидивного вузла в післяопераційному рубці правого передпліччя. При проведенні магнітно-резонансної томографії (МРТ) правого передпліччя візуалізується новоутворення 2,2×3,0×2,0 cм, що знаходиться в підшкірно-жировій клітковині із залученням власної фасції передпліччя. При комп'ютерній томографії (КТ) органів грудної порожнини (ОГП), органів черевної порожнини (ОЧП) та малого тазу не виявлено ознак метастатичного ураження.

Хворій проведено оперативне лікування в обсязі широкого висічення рецидиву пухлини правого передпліччя із пластикою ранового дефекту місцевими тканинами. При патогістологічному дослідженні відмічено зміну гістотипу дерматофібросаркоми на фібросаркому, що підтверджено імуногістохімічним дослідженням, відбувається втрата рецепторного статусу CD34, який у ДФСВ є позитивним у $>90 \%$ випадків. Дані патогістологічних висновків представлені на рис. 4.

У 2012 р. знову відмічено рецидив захворювання: при МРТ правого передпліччя виявлено новоутворення розміром $2,5 \times 3,3 \times 2,0$ cм, що знаходиться в підшкірно-жировій клітковині. 15.12.2014 р. проведено хірургічне втручання в обсязі широкого висічення рецидиву пухлини правого передпліччя із пластикою ранового дефекту місцевими тканинами. У патогістологічних висновках відмічено повну зміну структури на фібросаркому порівняно з попередніми даними (рис. 5).

У 2013 р. в пацієнтки спостерігається прогресування захворювання у вигляді місцевого рецидиву - виявлено новоутворення розміром $1 \times 2 \mathrm{~cm}$. Під час дообстеження - КТ ОГП та ОЧП, а також малого тазу метастатичних вогнищ не виявлено. 20.03.2013 р. хворій проведено хірургічне втручання в обсязі широкого висічення пухлини м'яких тканин правого передпліччя. У патогістологічних висновках відмічено зниження градації пухлини до G3 (рис. 6), у зв’язку із чим хворій з 05.04.2013 р. до 24.04.2014 р. проведено післяопераційний курс променевої терапії СОД 30 Грей.

У 2015 р. відмічено черговий рецидив пухлини правого передпліччя.

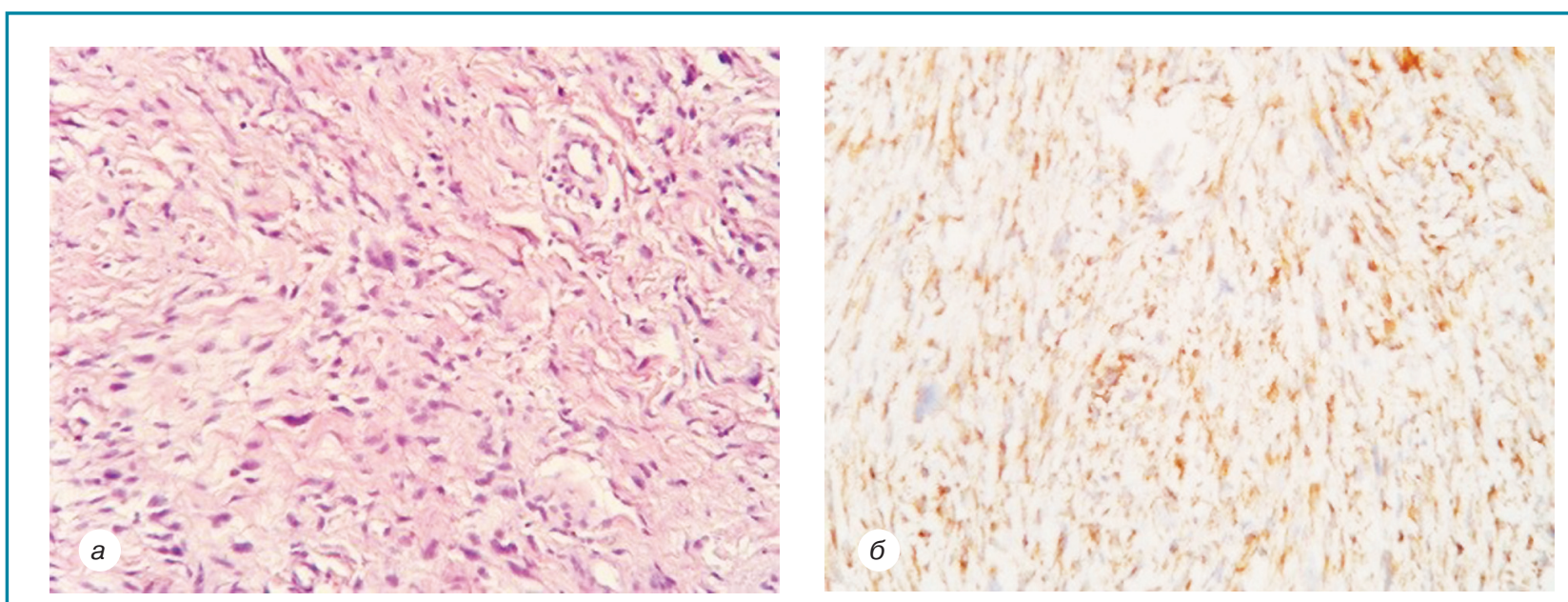

Рис. 2. ДФСВ G1; матеріал операції 1998 р.: a - забарвлення гематоксиліном та еозином, ×200; б - імуногістохімічне дослідження; Monoclonal Mouse Anti-Vimentin, Clone Vim 3B4 (Dako M7020), ×100, реакція позитивна 

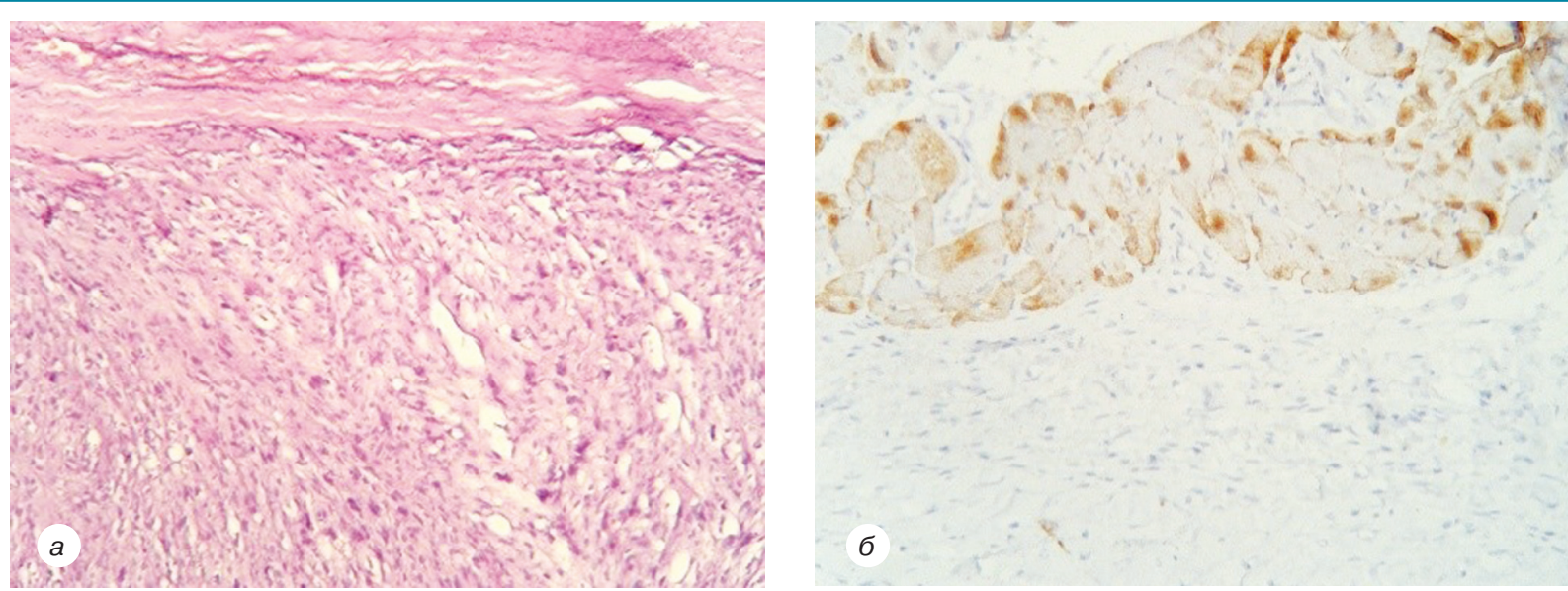

Рис. 3. ДФСВ G1; матеріал операції 2002 р.: a - забарвлення гематоксиліном та еозином, ×200, рецидив; б - імуногістохімічне дослідження; Monoclonal Mouse Anti-Human Desmin Clone D33 (Dako M0760), ×100, реакція негативна в клітинах пухлини, позитивний контроль у прилеглих поперечно-посмугованих м'язах
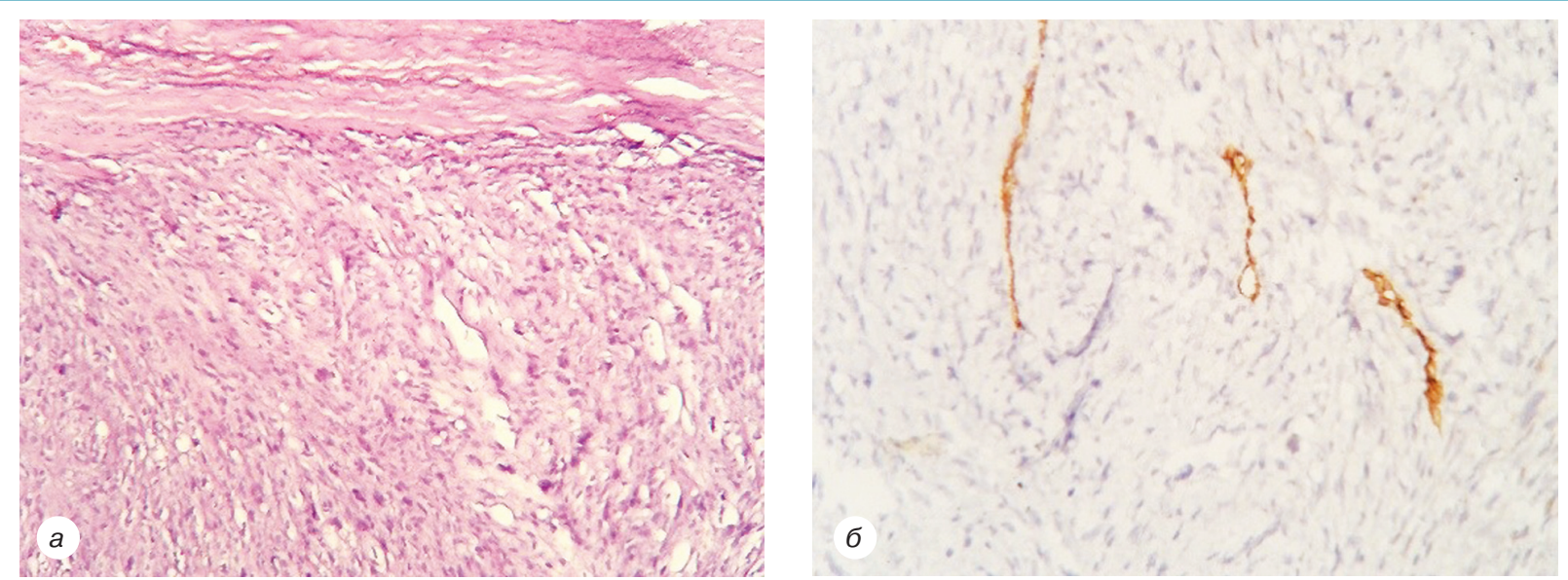

Рис. 4. Дерматофібросаркома з явищами патоморфозу у вигляді обширних некрозів, некробіозу і виражених дистрофічних змін пухлинних клітин і ділянками переходу у фібросаркому дорослих G2. Матеріал операції 2011 р.: а - забарвлення гематоксиліном та еозином, ×100; б - імуногістохімічне дослідження Monoclonal Mouse Anti-Human CD34 Class II Clone QBEnd 10 (Dako IS632), ×100, реакція негативна в клітинах фібросаркоми, позитивний контроль у стінках судин (при переході від дерматофібросаркоми до фібросаркоми дорослих відбувається втрата рецепторного статусу CD34, який у ДФСВ CD34 є позитивним у 90\% випадків)
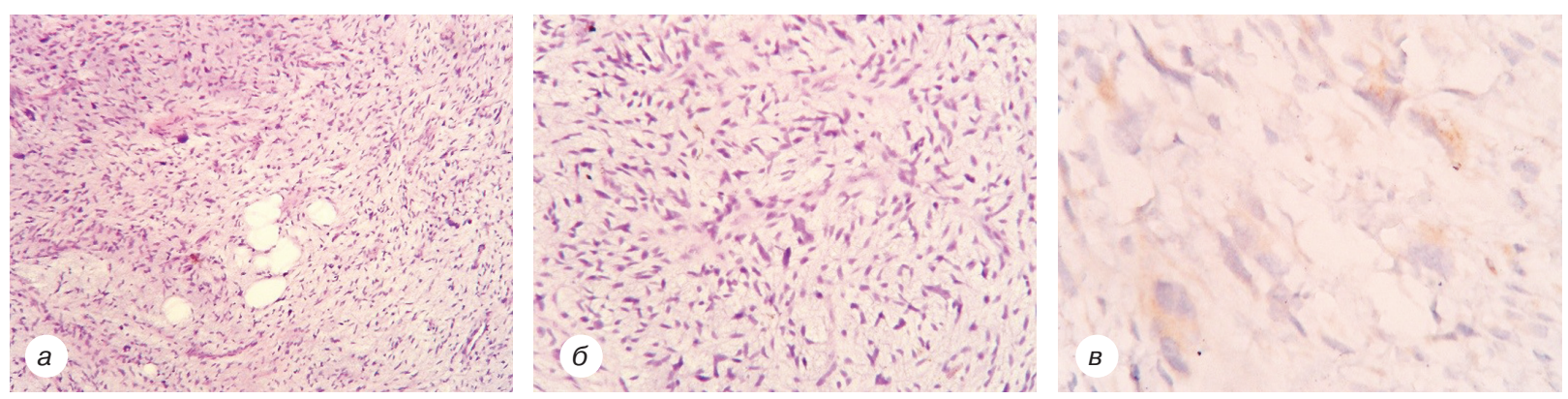

Рис. 5. Фібросаркома G2 з явищами некробіозу і вираженими дистрофічними змінами клітин пухлини; матеріал операції 2012 р.: a - забарвлення гематоксиліном та еозином, ×100; б - забарвлення гематоксиліном та еозином, ×200; в - імуногістохімічне дослідження; Policlonal Rabbit Antibodyto Platelet-Derived Growth Factor (PDGF) (DBS RP 145-05), х400, реакція позитивна

При дообстеженні шляхом МРТ правого передпліччя візуалізується новоутворення розміром $4,0 \times 3,3 \times 3,1 \mathrm{~cm}$, що знаходиться в підшкірно-жировій клітковині із залученням власної фасції передпліччя. При проведенні КТ ОГП, ОЧП та малого таза даних, що свідчать про метастатичне ураження, не виявлено.

Хворій 12.03.2015 р. проведено хірургічне втручання в обсязі широкого висічення рецидиву пухлини правого передпліччя 


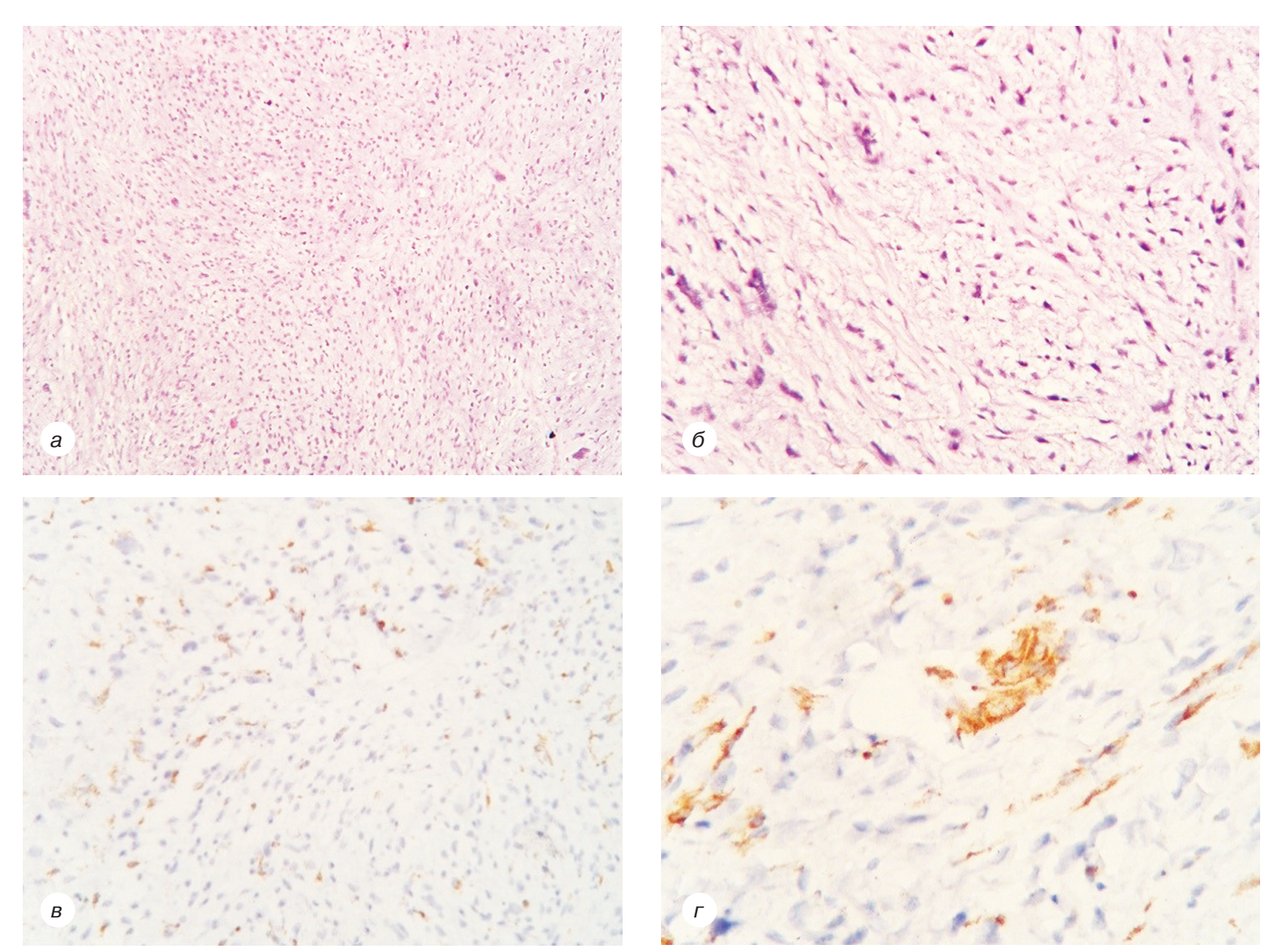

Pис. 6. Фібросаркома G3; матеріал операції 2013 р.: а - забарвлення гематоксиліном та еозином, ×100; б - забарвлення гематоксиліном та еозином, ×200; в - імуногістохімічне дослідження; Monoclonal Mouse Anti-Human CD68 Clone PG-M1 (Dako IS613), ×100; г- реакція позитивна, ×200
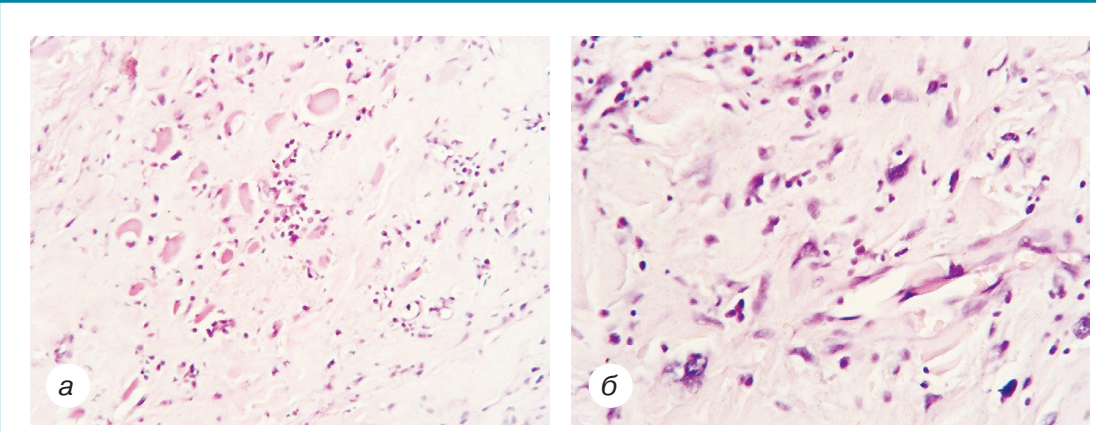

$B$

Рис. 7. Фібросаркома з явищами вираженого лікувального патоморфозу. Матеріал операції 2015 р.: а - забарвлення гематоксиліном та еозином, ×200; б - забарвлення гематоксиліном та еозином, $\times 400 ;$ в - імуногістохімічне дослідження; Monoclonal Mouse Anti-Human CD56 Clone 123C3 (Dako IR628), Monoclonal Mouse Anti-Human Cytokeratin Clone AE1/AE3 (Dako M3515), ×200, реакція негативна

із пластикою ранового дефекту місцевими тканинами. Дані патогістологічних висновків представлені на рис. 7.

3 березня 2015 р. і дотепер пацієнтка регулярно спостерігається в НІР, шо включає контроль КТ ОЧП, ОГП і малого таза та МРТ правого передпліччя кожного року. Станом на червень 2019 р. даних, що свідчать про прогресування, не виявлено.

\section{ВИСНОвок}

Представлене клінічне спостереження ще раз підтверджує складність і багатогранність розуміння процесу розвитку злоякісної пухлини й підкреслює необхідність правильного вибору лікування доброякісних новоутворень.

\section{СПИСОК ВИКОРИСТАНОЇ ЛІТЕРАТУРИ}

1. Alves, J. V., Matos, D. M., Barreiros, H. F., \& Bártolo, E. A. (2014). Variants of dermatofibroma - a histopathological study. Anais Brasileiros Dedermatologia, 89(3), 472-477. doi:10.1590/abd1806-4841.20142629.

2. Arnaud, E. J., Perrault, M., Revol, M., Servant, J. M., \& Banzet, P. (1997). Surgical treatment of dermatofibrosarcoma protuberans. Plastic and Reconstructive Surger, 100, 884-895. doi: 10.1097/00006534-199709001-00009.

3. Buehler, D., \& Weisman, P. (2017). Soft tissue tumors of uncertain histogenesis: A review for dermatopathologists. Clinics in laboratory medicine, 37(3), 647-671. doi: 10.1016/j.cll.2017.06.005.

4. Han, T. Y., Chang, H. S., Lee, J. H., Lee, W. M., \& Son, S. (2011). A clinical and histopathological study of 122 cases of dermatofibroma (benign fibrous histiocytoma). Annals of Dermatology, 23(2), 185-192. doi: 10.5021/ad.2011.23.2.185.

5. Herbert, T., \& Helwig, E. B. (1962). Dermatofibrosarcoma protuberans. A studyof 115 cases. Cancer, 15(4), 717-725. doi: 10.1002/1097-0142(196207/08) 15:4<717::aid-cncr2820150405>3.0.co;2-2. 
6. Lemm, D., Mügge, L. O., Mentzel, T., \& Höffken, K. (2009). Current treatment options in dermatofibrosarcoma protuberans. Journal of Cancer Research and Clinical Oncology, 135, 653-665. doi: 10.1007/s00432-009-0550-3.

7. Singh, R., Udager, A. M., Billings, S. D., \& Patel, R.M. (2019). Fibrous, Fibrohistiocytic, and Myofibroblastic Tumors of Intermediate Malignancy. Soft Tissue Tumors of the Skin. New York: Springer.

8. Szollosi, Z., \& Nemes, Z. (2005) Transformed dermatofibrosarcoma protuberans: a clinicopathological study of eight cases. Journal of clinical pathology, 58(7), 751-756. doi: 10.1136/jcp.2004.019349.

9. Toro, J. R., Travis, L. B., Wu, H. J., Zhu, K., Fletcher, C. D., \& Devesa, S. S. (2006). Incidence patterns of soft tissue sarcomas, regardless of primary site, in the surveillance, epidemiology and end results program, 1978-2001: An analysis of 26,758 cases. International Journal of Cancer, 119(12), 2922-2930 doi: 10.1002/ijc.22239.

10. Weedon, D., \& Weedon, D. (2002). Skinpathology. London: Churchill Livingstone.

11. Winchester, D., Lehman, J., Tello, T., Chimato, N., Hocker, T., Kim, S., ...\& Arron, S. T. (2018). Undifferentiated pleomorphic sarcoma: Factors predictive of adverse outcomes. Journal of the American Academy of Dermatology, 79(5), 853-859. doi: 10.1016/j.jaad.2018.05.022

\section{Клинический случай трансформации дерматофибромы в фибросаркому}

В.В. Остафийчук, С.И. Коровин, М.С. Кротевич, Н.Н. Кукушкина, C.A. Дедков

\section{Национальный институт рака, Киев}

Резюме. Путь трансформации доброкачественного новообразования в злокачественную опухоль достаточно сложный и до настоящего времени мало исследован. Описан клинический случай длительной трансформации (23 года) доброкачественной фиброзной гистиоцитомы (дерматофибромы) в дерматофибросаркому выбухающую, которая в дальнейшем трансформировалась в фибросаркому.
Ключевые слова: доброкачественная фиброзная гистиоцитома (дерматофиброма); дерматофибросаркома выбухающая; фибросаркома; клинический случай.

\section{Clinical case of dermatofibroma transformation in fibrosarcoma}

V.V. Ostafiichuk, S.I. Korovin, M.S. Krotevich, M.M. Kukushkina, S.A. Dedkov National Cancer Institute, Kyiv

Summary. The pathway of the transformation of benign neoplasm into a malignant tumor is rather complicated and has not so far been studied extensively. The clinical case of long-term transformation (23 years) of benign fibrous gistiocytoma (dermatofibroma) in exploded dermatofibrosarcoma is described, which was subsequently transformed into fibrosarcoma.

Key words: benign fibrosisgistiocytoma (dermatofibroma); exploded dermatofibrosarcoma; fibrosarcoma; clinical case.

Адреса для листування:
Остафійчук Василь Васильович
03022, Киї, вул. Ломоносова, 33/43
Національний інститут раку
Tел.: (044) 257-99-46
E-mail: lugnik2007@gmail.com
C3/43 Lomonosova Str., Kyiv 03022
Ostafichuk Vasyl
Nenal.: (044) 257-99-46
E-mail: lugnik2007@gmail.com

